\title{
Constructing Rural Natures
}

Link to publication record in Manchester Research Explorer

\section{Citation for published version (APA):}

Castree, N., Braun, B., \& Marsden, T. (Ed.) (2006). Constructing Rural Natures. In The Handbook of Rural Studies (pp. 161-170). Sage Publications Ltd.

\section{Published in:}

The Handbook of Rural Studies

\section{Citing this paper}

Please note that where the full-text provided on Manchester Research Explorer is the Author Accepted Manuscript or Proof version this may differ from the final Published version. If citing, it is advised that you check and use the publisher's definitive version.

\section{General rights}

Copyright and moral rights for the publications made accessible in the Research Explorer are retained by the authors and/or other copyright owners and it is a condition of accessing publications that users recognise and abide by the legal requirements associated with these rights.

\section{Takedown policy}

If you believe that this document breaches copyright please refer to the University of Manchester's Takedown Procedures [http://man.ac.uk/04Y6Bo] or contact uml.scholarlycommunications@manchester.ac.uk providing relevant details, so we can investigate your claim.

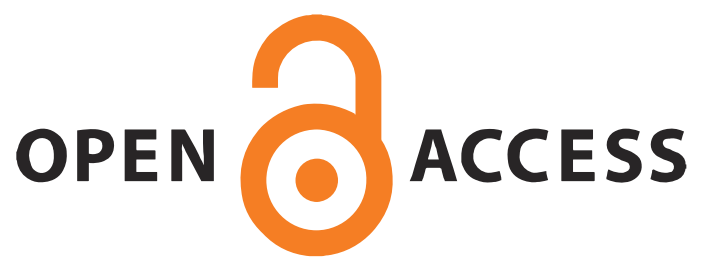




\title{
B Nature
}

\section{Constructing rural natures}

\author{
Noel Castree and Bruce Braun
}

the tactic of ... revealing nature to be a 'social construct' has lost much of its initial intellectual potency. (Bartram and Shobrook, 2000: 370)

\section{INTRODUCTION}

As our epigram suggests, this is an inauspicious moment to consider the constructedness of rural natures. In relation to those myriad things conventionally labelled as 'natural', rural studies is fast entering a 'post-constructivist' moment. ${ }^{1}$ Today the non-human is being granted a constitutive role in rural life within a non-dualistic, antiessentialist worldview. This moment follows hard on the heels of nature's 'return' to rural studies from the late 1980s and through the 1990s. Over a decade ago, nature gained a long overdue place on rural researchers' agendas by, paradoxically, being de-naturalized. As we shall demonstrate in this chapter, the idea that rural natures were socially constructed inspired 10 years of interesting and important research. Today, though, enthusiasm for the social construction thematic is on the wane. In rural studies, as in several other research fields (like human geography and environmental sociology), this is because the philosophical limits of constructionist arguments have been exposed (see Chapters 12 and 13, this volume). This is a positive development because it has opened the door for approaches to rural natures that do not rest upon ontological separations and the explanatory-normative frameworks that such separations have inspired.

Having, in one sense, pulled the rug from under ourselves, why write about rural studies, nature and social constructionism at all? Our answer is three-fold. First, it is easy to overlook the considerable strengths of constructionist approaches. While post-constructivist frameworks such as actornetwork and non-representational theory ${ }^{2}$ may now be paradigmatic for many rural researchers, we forget at our peril the considerable intellectual and political resources that constructionism still provides. For instance, while the baroque jargon of some academics might declare that a societynature dualism never existed, it none the less continues to animate thought and action in myriad everyday sites and situations. 'Wilderness', for instance, is still an immensely important organizing concept in and for rural North America, while the 'rural idyll' still resonates in Britain. Even now, then, the constructionist move of de-naturalizing that which seems self-evidently 'natural' can still be a powerful and productive one. In the second place, we also want to argue that despite its familiarity as a catch-phrase, rural researchers have not always been entirely clear on what 'social constructionism' means. This is because there is no such thing as a generic social constructionist position, only specific modalities of social constructionism. Yet few in rural studies have bothered to tease out the differences of degree or kind between these several strands of social constructionist argument. As David Demeritt (2002: 768) notes, "The " "social construction of nature" is spoken about in such different and often imprecise ways that its [exact] ... meaning and implications can 
be difficult to understand and evaluate'. Finally, there may be good reasons to question whether the 'post-constructivist' moment is really the radical break it seems to be. We argue that it should be considered a realization of certain themes within the social constructionist problematic that have, for too long, been confined by unhelpful ontological suppositions.

We hope, then, that this chapter at once clarifies and pushes to the limit what is meant by the 'construction' of nature. The chapter is organized as follows. In the next section we introduce the 'question of nature' in rural studies and revisit the moment when the field experienced its 'constructionist turn'. We do this to remind readers why constructionism proved such an appealing approach for several years from the late 1980s onwards. Following this, we identify several types of constructionist argument. In the third section we then discuss the limits of otherwise different constructionist approaches to rural natures. Despite appearances, this critique does not imply a wholesale abandonment of constructionist positions. Although that is one possible implication, we argue that strategic retention of these positions can still be justified. This said, we conclude that social constructionism will soon have very few rural researchers willing to sing its explanatory and normative praises.

\section{RURAL STUDIES, NATURE AND THE 'CONSTRUCTIONIST TURN'}

In an oft-cited review of rural studies in the mid-1990s, Paul Cloke (1997: 371) detected 'strong moves to reclaim ... nature as a legitimate and provocative component of [a] reconstructed rural studies'. Even if one acknowledges that the conventional idea of rural spaces being somehow more 'natural' than urban ones is misconceived, it is still surprising how marginalized nature was in post-war (and especially post-positivist) rural studies discourse. To the extent that it figured at all it was either a backdrop or a taken-for-granted aspect of rural life rather than a formal subject of analysis. For instance, in a wide-ranging late 1980s' review of rural geography Cloke found no reason to mention nature at all. Yet within a few years nature was on the rural studies agenda (and Cloke's own agenda) in two important ways. On the one side, concerns about environmental degradation and the need for 'sustainability' led some to focus on nature as a biophysical entity with identifiable capacities, limits and (in the case of sentient nonhumans) even rights. In the case of several Marxists - like George Henderson (1999: part I) this focus was inspired more by a curiosity about how 'natural barriers to accumulation' are overcome in farming. But in most cases it has arisen from a concern about environmental degradation and the loss of non-human species. On the other side, several rural researchers took a less realist tack and sought to explore the non-naturalness of nature. In so doing they partook of a wider constructionist turn in the social sciences and humanities regarding 'nature' and collateral concepts such as 'race', sexuality, biology and environment. This turn gathered momentum through the mid-tolate 1980s. Among the first rural studies publications that used the term 'social construction of nature' in a substantive sense were Lowe et al. (1990) and Maunder et al. (1993). Subsequently, numerous empirical and theoretical studies were published that applied, finessed and extended social constructionist ideas.

The positive legacy of this two-pronged engagement with nature lives on today. At present there are several rural researchers still mining these two research veins, while the critique of the society-nature dualism underpinning both has, as noted in the introduction, propelled still other researchers into innovative new domains of inquiry. Though this latter cohort of postconstructivist researchers eschew any literal use of the label 'nature', they none the less remain profoundly concerned with the entities this signifier has traditionally named. As Rouse (2002: 69) explains, 'If the post-constructivist tradition denies that there is any role for "unreconstructed nature" in our understanding ..., it is not because we are able to get "outside" of a relatively selfenclosed social world, but because we have never been "inside" one in the first place.'

As a result of these various developments, contemporary rural studies takes nature seriously in several different ways. Though we do not wish to engage in pedantic boundary disputes over where 'rural studies' begins and ends, the following is just a brief list of some of the topic areas where nature currently figures in rural researchers' inquiries: environmental governance; agribusiness; images of rural life; rural wildlife and domesticated animals; commodity chains and food networks; organic farming; post-productivist 
landscapes; the body; environmental knowledges (lay and expert); and agricultural biotechnology. The theoretical pluralism of rural studies means that in these and other topic areas nature is approached in various (often incompatible) ways. But prior to our current post-constructivist moment, it is fair to say that several theoretical perspectives shared a common commitment to a constructionist worldview. We will review these perspectives in the next section. For now, we simply want to speculate about why constructionism made such a splash in rural studies from the late 1980s until quite recently.

The philosopher of science Jeff Coulter (2001: 82) recently suggested that constructionism is "more a shibboleth than a coherent domain of ... theorizing'. Though many would doubtless agree, it would be remiss to forget that the term 'constructionism' meant something quite definite when it became a watchword in a range of Anglophone academic disciplines more than a decade ago. Typically associated with academics who would class themselves as 'left wing' in some sense or other, the term 'social construction' was first popularized in a famous text by Berger and Luckmann (1967). According to Steven Vogel (1996), though, its deeper origins lie in Georg Lukacs' (1971) seminal critique of fetishism and reification (itself based on a creative reading of Hegel's philosophy). We mention this because it seems to us that the turn to social constructionism in rural studies (as well as a number of other fields) was motivated by a desire to reap the rewards of a double critique: namely, a critique of misrecognition and hypostatization. Let us explain.

When some rural researchers re-discovered nature in a realist rather than constructionist sense in the early 1990s their actions were entirely predictable. After all, these researchers seemed to be confirming the common-sense idea that rural areas are more profusely natural than towns and cities. What could be more sensible - and important than examining the ecological limits of agriculture, the state of rural wildlife or the restoration of hedgerows, dry-stone walls or beaver habitats? For constructivists the answer to this question was that de-mystifying nature was more intellectually and politically rewarding. 'Nature', we can hardly forget, has long been a polysemic weasel-word. As William Cronon (1991: 36) rightly insisted, 'We cannot fall into the trap this word has laid for us.' For constructivists, the 'problem' with nature was that its apparent givenness and obviousness was precisely what shielded it from critical scrutiny. To suggest that nature was 'constructed' was thus - given the unproblematized naturalism characteristic of pre-1990s rural studies - radical and liberating. The term construction, rich in its meanings, describes not only a process and an end product but also an act of conceptual construal. Its invocation was a caution against the easy rediscovery of an asocial, biophysical nature that had quietly inhabited rural researchers' ontological worldviews for several decades. It was also a corrective to the 'common-sense' move of equating rural things with natural things.

This had two dimensions. First, the "constructionist' label suggested that natural things - fields, crops, water-courses, wolves or what-have-you were often social things in a cunning disguise. The 'rural idyll', for example, could be shown to be a culturally specific and normatively loaded image rather than a faithful depiction of an evergreen countryside (Bunce, 1994; Mingay, 1989). Secondly, this exposure of routine acts of misrecognition was linked to critique of hypostatization. To hypostatize something is to ossify and freeze it when, in fact, the thing so conceived is part of a changeable and dynamic process. To show that apparently natural (and thus 'given') things are, in fact, mutable social constructs was thus very appealing for several rural researchers. It allowed them to contest acts justified in the name of nature. It allowed them to highlight the social relations animating apparently non-social ideas or entities. It enabled them to show that 'nature' was a medium for the expression of power relations. And it offered them the chance to imagine alternative social and ecological arrangements that honestly confronted the non-naturalness not just of ideas of nature but also the phenomena those ideas referred to. In short, the constructionist motif was very empowering for a cohort of 1990s rural researchers and remains so for several of them today. In a sense, 'nature' became a metaphor for these researchers: one which connoted the duplicity of appearances, the hidden hand of power and misplaced concreteness of the visible and perceptible.

Before we end this section, it is worth recalling what has been implicit in the paragraphs above: namely, that constructionist analyses of nature have been an important vehicle for the importation of putatively 'critical' theories into rural studies. We say importation because, as we shall show below, rural researchers have produced 
little in the way of 'indigenous theory' when it comes to analyses of nature. The specifically 'rural' dimension of the natures being deconstructed and denaturalized has, in the main, had no wider theoretical consequences. The one major exception to this, perhaps, is agro-food studies, where the materiality of rural natures has led to a reworking of concepts imported from Marxian political economy, regulation theory and the like. Notwithstanding the theoretical insignificance of rurality per se, the constructionist approach to nature was, during the 1990s, important in building a post-positivist momentum in rural studies that persists to this day. From our perspective this is all to the good. Social constructivism may no longer be a live option in rural studies - a result, no doubt, of the ennui that sets in with all intellectual-political 'turns' within academia. But neither should constructivism be dismissed as a thing of the past - as no more than a curiosity to be dissected and discarded. Instead, it has provided critical leverage for new and productive avenues of inquiry that animate rural studies. We will discuss these new avenues later. But let us first map the landscape of constructionist analyses of nature in rural studies.

\section{PLURAL CONSTRUCTIONS, MULTIPLE NATURES}

The term 'social construction' has become almost hackneyed through over-use in a range of disciplines. According to Coulter (2001: 82), 'this feeds the suspicion that it has become virtually devoid of intellectual substance'. Though this suspicion is hardly groundless it is certainly not accurate. As we now try to anatomize constructionism, bear in mind that we are inevitably interposing our own conception of 'construction' in order to place some limits on the material reviewed here. Social constructionist arguments in rural studies (as in other fields) have not always announced themselves as such. For several commentators (like Cloke, 1997), they are the preserve of those on the 'cultural left' of rural studies. But this is surely too narrow an interpretation. Constructionism does not beginand-end with 'post-prefixed' approaches like Derridean post-structuralism - though this is often assumed to be the case. A more generous interpretation encompasses some political-economy perspectives on nature and actor-oriented studies of the rural, among others. This widening of the constructionist label is not merely a nominal issue. Real intellectual and political differences are obscured when we mis/label some approaches to rural natures 'constructionist' and others not. Finally, we should note that outside the rural studies field there are now several excellent surveys of the constructionist approach to nature (see Demeritt, 1998, 2001, 2002; Hacking, 1999). Demeritt, for example, offers a six-fold typology of constructivist analyses, straddling the distinction between broadly discursive (or representational) and material (or ontological) approaches. However, since Demeritt's and other surveys do not map neatly onto rural researchers' approaches to nature we choose not to use them in any rigid sense here.

We mentioned above that the term construction describes both a process and a product. There have, in our view, been three broad modes of constructionist argument in contemporary rural studies and we can think of each in terms of the process(es) and product(s) they specify. First, there are material constructionisms that consider nature as a physical domain. Secondly, there have been discursive constructionisms that look at ideas, representations and images of rural nature. Finally, there have been material-semiotic constructionisms that encompass materiality and discourse within one analytical frame. Let us take each in turn and offer some illustrative examples.

Post-war rural studies, as we observed earlier, operated with an unproblematized and largely implicit realist conception of nature up until the mid-to-late 1980s. Material constructionism challenged this by suggesting that rural natures, in the bio-physical sense, were not simply 'given'. This argument was made most forcefully by Marxist and neo-Marxist researchers such as Fred Buttel, David Goodman, Jack Kloppenburg and George Henderson. And it was made in relation to those elements of rural nature most subject to conscious material manipulation: namely, crops and cattle. These authors argued that a definite set of social processes, structures and relationships - variously described as 'capitalism', 'industrialism' and 'Fordism', among others - were physically transforming certain rural natures. The 'weaker' version of material constructionism argued that biophysical natures can only be defined relative to the socio-economic systems of production in which they are entrained. This meant that the 'naturalness' of a putatively non-social nature was, in fact, contingent and shifting not absolute and stable. Mann 
and Dickinson's (1978) pioneering work on how capital moves around 'natural barriers to accumulation' was an early example of this weak material constructionism. A stronger version of physical constructionism argued that rural natures were being materially reconstituted. For instance, Kloppenburg's (1986) First the Seed explained how the 'real subsumption' of biology to capital was possible once the science of hybridization was established in the early twentieth century. This subsumption is an example of what the geographer Neil Smith (1984) called the 'production of nature', a term which suggests that everything from crops to broiler chickens are now mere means to the end of capital accumulation. Given the intensified biochemical alteration of crops and livestock in the current era, Kloppenburg's analysis was, in retrospect, most prescient (see also Prudham, 2003).

This Marxist work illustrates the strengths of material constructionism as an approach to rural nature. First, this research dispelled the 'myth' that rural areas are home to nature by showing that the nature in question was, increasingly, artificial. What's more, this research showed that the social forces remaking nature on farms and in fields extended beyond the rural realm. As Cronon's (1991) classic (though non-Marxist) analysis demonstrated, if what happens in the country is systematically linked to what happens in the city then 'rural nature' cannot simply be rural or natural any more (see also Brechin, 1999). This theme has, more recently, been the focus of research into agricultural commodity chains, rural industrialization, the regulation of rural production and world food systems (see, for instance, Goodman and Watts, 1997). Secondly, Marxist material constructionisms offered new political, as much as analytical, possibilities. They focused rural researchers' attention onto a key question: namely, who constructs rural natures in what ways, to what ends and with what consequences? Asking this question did two important things simultaneously. On the one hand, it nipped any unreflexive forms of ecocentrist politics in the bud by showing that nature can never be considered separately from specific forms of societal organization. On the other hand, it opened up the possibility of a politics that would seek to remake nature for different socio-ecological ends than those dominant in capitalist societies. In short, by de-reifying rural nature, material constructionisms promised to avoid the Scylla of a naïve naturalism and the Charybdis of a Promethean disregard for nature. This said, one must concede that few Marxist rural researchers have paid much heed to the materiality of constructed nature in its own right and less still to what a political-normative theory of this 'un-natural nature' might look like. In the main, these researchers have paid little attention to the agency of a transformed material nature nor to the evaluative schema one might use to judge the propriety of how this nature is being remade.

The economic and physicalist emphases of Marxist rural research was, in many ways, unusual within the wider rural studies 'turn' to nature from the 1980s onwards. Like much of the social sciences and the humanities, rural studies became swept up in two other turns that informed its new-found interest in nature: namely, the linguistic and the cultural. The latter, of course, were not entirely un-Marxist in the theoretical sense. The works of Gramsci, Stuart Hall and Raymond Williams, for instance, were key influences. But in rural studies, if these figures were appropriated at all, it was rarely in conjunction with an attempt to understand the material construction of nature. George Henderson's (1999) work California and the Fiction of Capital remains one of the few exceptions. His analysis of the material remaking of early twentieth century Californian agriculture is accompanied by a sophisticated analysis of the discourses of rural nature that accompanied this physical transformation. Specifically, Henderson analyses such seemingly disparate representational devices as adverts and novels to show how different actors in the Californian landscape made flesh their attempts to exert power and express resistance. The Marxian notion of ideology he works with shows how representations of rural nature serve certain interests that are, in turn, dialectically structured by the economic and ecological context in which they are situated. His point is not that representations conceal 'what's really happening' but, rather, that they are material forces in their own right that capture partial truths about their context.

Most rural researchers interested in the discursive construction of nature have, unlike Henderson, focused on discourse alone. Indeed, it is probably fair to say that representations of nature became privileged subjects of analysis in rural studies during the 1990s. This was, no doubt, a legacy of the wider enthusiasm within Anglophone academia for the ideas of Derrida, Foucault, Barthes, Rorty and for those other (usually continental European) theorists preoccupied with the 'power' 
of language and the performativity of knowledge. Initially, the focus on representing rural natures was counter-intuitive, and that was its appeal. After all, in post-war rural studies as much as in the wider society, representations were usually considered to be more-or-less neutral 'mirrors'. This was most obvious in rural studies' positivist phase but even by the late 1980s there was something novel and arresting about denaturalizing representations of rural nature. These deconstructive manoeuvres took several forms in relation to several aspects of nature. The most general was the argument that the rural itself was a culturally constructed idea (not an empirical given) and that its contingent meaning depended upon equally contingent depictions of nature - an argument that went back to Williams's (1973) The Country and the City. As Little (1999: 440) put it, while "nature cannot be conflated with the rural, the countryside does represent one commonly identified spatialization of nature'. Others, more specifically, anatomized particular written, spoken and visual representations of rural nature - not in their own right but as elements within wider taken-forgranted grids of cultural understanding. These kinds of analyses were a key means whereby nonMarxist approaches were able to find a place in rural studies. Feminists, anti-racists and critics of heteronormativity, in particular, were able to show the gender, racial and sexual (not merely class) inflections of many hegemonic understandings of rural natures - be they the 'frontier' lands of the United States, the 'great outdoors' of the Antipodes, or the British fox-hunting countryside. Sibley (2003), among others, has shown how these understandings structure individual and group self-understandings and so become, in a very literal sense, lived. This is most evident in research into rural identities that shows how conceptions of, and practical engagements with, the natural world define stereotypical selfunderstandings of manliness, femininity and sexuality (e.g. Brandth, 1995; Bryant, 1999).

However, not all research on rural representation has been indebted to critical post-Marxist (and non-Marxist) theory or to continental linguistics, philosophy and psychoanalysis. For instance, the Wageningen School of rural research is more actor-oriented, looking at how different knowledges of rurality and nature issue from different rural actors because of their location within wider social relations and networks (see, for instance, Haan and Long, 1997). Likewise, a lot of
English-speaking research on 'expert' and 'lay' understandings of rural issues is micro-sociological in approach and interested not just in how constructed bodies of 'local knowledge' inform action but in how the legitimacy of those knowledges is challenged and changed (e.g. Lowe and Ward, 1997).

We do not have space here to typologize discursive constructionisms in rural studies. In any case, the emphasis of research into representations of rurality and nature has shifted in recent years, as we will see below. Suffice it to say that the discursive constructionisms mentioned above are not all of a piece, except perhaps in that they share some broad strengths that explain why many rural researchers caught discourse fever through the 1990s. First, they gave long overdue recognition that representation 'matters' in both senses of the term (that is, it is important and has tangible effects). Given the conventional view of nature as something given not made, this recognition was especially important. It also allowed researchers to show that specific and contestable depictions of nature typically disavowed their own constructedness. Furthermore, it allowed these researchers to show that representations of nature, in one sense, create the 'realities' they purport merely to convey. Thirdly, this demonstrated that there is a politics of representation to be uncovered in which power and resistance are involved (see Maunder et al., 1993). 'Mere representations' of nature were shown to be key sites of struggle that can materially affect people as much as the non-human world. It is worth noting that, on the whole, discursive constructionism in rural studies has functioned as what Demeritt (2002) calls 'philosophical critique' rather than as 'refutatory critique'. The latter aims to expose the mis-representations that delude onlookers about the 'realities' of their world. Philosophical critique, by contrast, argues that there is no way to understand those realities that escape "the looping effect through which conceptual change transforms what has been conceived' (Rouse, 2002: 76).

If these insights now seem rather passé it is because discursive constructionism has become such a central part of the rural studies landscape. But there is a third form of constructionism in rural studies that pushes beyond both the discursive and the material version and which has become prominent in the past few years. It is a materialsemiotic form of constructionism that aims to link the discursive and the physical together. We have 
already mentioned Henderson's work as one example of this. But Henderson, arguably, ultimately separates the discursive and the material, albeit as what David Harvey (1996) would call related 'moments' within a complex but continuous process. Other rural researchers, by contrast, fuse the two. They do so not, as might be supposed, by resorting to motifs like dialectic, interaction, or system. Rather, they aim to remove the representation-reality distinction that underpins these otherwise appealing motifs. Counterintuitively, they do so by deepening the notion of discursive constructionism so that it describes a seamless process of materialization.

An example is Braun's research on rural British Columbia. Writing in the wake of Butler's (1993) adaptation of Derrida to the question of the human body, and of Foucault's work on governmentality, Braun (2000) seeks to avoid any hint of cognitive dualism or 'ontological outsides' of discourse. He shows how geologists like George Dawson 'ordered' and 'enframed' rural British Columbia such that there was never any possibility of a selfevident nature 'beyond discourse' whose raw materiality could be directly apprehended. This is not the same as saying that language physically 'constructs' those things that have conventionally been labelled as both 'rural' and 'natural'. Rather, it is to suggest that understandings of, and interactions with, those things cannot be separated from the discursive practices that make them available to calculation such that there is 'an implosion of the epistemological and the ontological' (2000: 14). This implosion is possible once one realizes (or accepts) that (i) there is no clear-cut outside of language and representation and that (ii) language and representation are practical, world-making devices not passive mirrors of something external to themselves. Braun's 'flat' philosophical worldview suggests that discursive representations are practical tools that help matter to 'materialize' for us both visibly and physically (see also Braun, 2002). It is a worldview that pushes beyond earlier work on representations as 'lenses' that interpose themselves between the physical world and people (Braun, 1997).

The contrast with Henderson's work is instructive, marking the difference between materialsemiotic constructionisms informed by Marxian theory and those informed by leading French philosophers. Henderson is ultimately a 'materialist' in the sense that the physical environment and the material structure of society together condition the sorts of representations of rural nature that become hegemonic at any moment in history. Braun, by contrast, does not ultimately subordinate the discursive to the material in this way because he sees no ready distinction between the two. This is not to suggest that material-semiotic constructionisms like Braun's trump those expounded separately by rural researchers preoccupied with either discourse or the material environment. At base, one might suggest that the plurality of constructionist positions in rural studies reflects an ongoing uncertainty about two things. The first is what the 'ontological units' of analysis should be in constructionist analysis (that is, where does one draw distinctions so that meaningful 'noun chunks' of reality can be identified). The second is what the causal link between these ontological units is (that is, how does one theorize the relation between a constructing process and a constructed idea or object?).

\section{BEYOND CONSTRUCTIONISM?}

For all their strengths, one of the paradoxes of constructionist approaches to nature is that they break down the 'common-sense' separation of society and nature only to (i) reinstate it at another level or else (ii) erase nature altogether. As we saw in the previous section, the 'classic' constructionist move is to denaturalize nature by bringing it - either discursively or biophysically (or both together) - within the realm of the social. But this boundary-transgressing act is only apparently non-dualistic. Depending on the specific modality of constructionism in question, it can reinstate a society-nature divide in several other registers. For instance, claims about the discursive construction of rural natures often imply - by default - that a 'real' nature lies beyond the lattices of language. Where a nature-society dualism is not reinstated it is often (again implicitly) replaced by a monism, whereby what we call nature is almost completely eclipsed. For instance, the argument that many elements of 'nature' in rural settings are biophysically remade 'all the way down' by agri-business gives most of the motive power to capital. Likewise, the non-dualist approach of Braun risks ignoring the agency and affordances of those things that become intelligible to people through their labelling as 'natural'. So what becomes of nature here? We ask this question not to imply that some constructionisms need an antidote of good old-fashioned realism-cumnaturalism. For realism usually partakes of the same 
society-nature dualism we have just questioned. Rather, we are concerned to know how the presence and agency of what we happen to call 'nature' can be registered without getting stuck on the horns of an irresolvable constructivist-realist dilemma. Equally, we are concerned to know what role those things heretofore captured by abstractions like 'society' or 'social power' play in relation to putatively 'natural' phenomena. These twin concerns are starting to be addressed in rural studies as integral parts of the field's current postconstructivist trajectory.

'Our ontological choices', David Goodman (2001: 182) avers, 'are consequential.' We couldn't agree more. The choices constructionists make (consciously or not) circumscribe as much as they enable. So what is wrong with the dualistic worldview underpinning social constructionist arguments (and their realist counterpoints)? Two problems loom large. First, to say that nature is socially constructed is to grant 'the social' (be it capitalism, culture, discourse or what-have-you) an unwarranted degree of materiality and integrity. While it is possible to 'cut the world at the joints' conceptually, at the ontological level what we call 'the social' cannot be materially disembedded from what we call 'the natural'. Secondly, this suggests that we live (and have always lived) in a world of 'distributed materiality' where the actions of 'social' and 'natural' phenomena upon one another is a relational achievement not a case of discrete domains colliding with, controlling or subsuming the other. It thus seems to make little sense to talk about a 'socially constructed nature' just as, conversely, it is unhelpful to talk about an 'asocial nature' that has an independent materiality and ethical value. Arguably, we need a 'postsocial' conception of 'rural natures' that is, at the same time, a post-natural one too (cf. Knorr Cetina, 2001). In short, for many critics in rural studies and beyond, we need a synthetic, symmetrical appreciation of 'socionatures'.

There are at least four ways in which rural researchers, and other social scientists with interests in nature, have sought to move beyond the social constructionist problematic in recent years. First, some have embraced the actor-network theory (ANT) pioneered and popularized by Bruno Latour and Michel Callon (e.g. Murdoch, 2003). There are arguably two reasons why ANT has appealed to several rural researchers. One is that it provides an elaborate conceptual vocabulary (including neologisms like 'actants' and 'intermediaries') that can be readily put to work in new research contexts. The second reason is that Latour, Callon and other like-minded theorists have a strongly empirical focus to their work. Given rural studies' previous aversion to theory (until the 1980s), the empirical cast of ANT has proven congenial to many in the field because it chimes with their 'grounded' sensibilities (e.g. Eden et al., 2000). Secondly, some rural researchers have been inspired by the ontologies of force and practice expounded by Deleuze, Guattari, Grosz and other relational philosophers. Thrift (2003: 309), for example, has used some of the latter's 'portentous philosophical statements' to consider how both human bodies and non-human phenomena are entangled in country life. Thrift's vision is of rural worlds where numerous assemblages of bodies, matter, extension and action both endure and yet churn in non-essential ways. Thirdly, Thrift's own 'non-representation theory' and a wider precoccupation with 'performance' in cultural studies has inspired others to examine the iterative co-constitution and remaking of bodies, identities, species and landscapes in rural places. This dovetails with a 'dwelling perspective that accents the mundane practices of engagement through which people's identities and corporealities are configured and the non-human world is fashioned (Wylie, 2003). This dwelling perspective suggests that human actors learn by doing not simply by knowing, where learning encompasses patterns of thought, bodily habits, physiology, sight, smell and sound. Finally, and moving more into the realm of ecological science, some rural researchers have been inspired by new thinking about how energy and matter pass between people and the non-human world. This new ecological thinking looks at how complexity, disequilibrium and scale-switching all animate human-non-human connections (see Zimmerer, 2000).

Much of this relational thinking is examined elsewhere in this volume; this is why we do not want to discuss it in any detail here. However, we do want to acknowledge that relational approaches offer a promising means of bringing nature 'back in' to rural studies without reverting to a rather rigid realism. Earlier we mentioned those rural analysts with interests in species and habitat loss, conservation policy and environmental pollution. We also observed that what was missing from rural studies' 'constructionist turn' during the 1990s was a due acknowledgement of the materiality of those things we conventionally class as 
natural things. The relational approaches listed above give analysts the chance to take nature seriously in explanatory and moral terms - be it the fleshy body or the non-human domain. But they all do so, in effect, by doing away with the category of nature altogether in order to explore how different worldly actors with diverse capacities and affordances co-constitute one another.

\section{CONCLUSION}

In light of our arguments in the previous section it would not be difficult to conclude with a Latourian turn of phrase. 'We've never been constructivists!' could easily be our refrain. But such a conclusion, aside from glibly calling the work of numerous rural researchers into question, also neglects the positive role constructionist analyses can still play today. There is no neutral ground on which to compare the relative merits of constructionist and post-constructionist approaches. The former denaturalizes rural natures, while the latter questions whether there are discrete 'social' processes that create discernible 'constructions' representationally and/or materially. Given the incommensurability of these two paradigmatic approaches to rural natures, all we can do is ask the pragmatic questions: what kinds of moralpolitical visions and practical actions are mandated by each approach?; and do we find those visions and actions to be worthy ones? If one chooses to retain the philosophical assumptions underpinning most constructionist positions then the original advantages (detailed in the second section of this chapter) of the denaturalizing argument remain useful today. The exposé of misrecognition and hypostatization still carries force, as does the kind of refutatory critique intrinsic to many social constructionist approaches in rural studies. Also, let us not forget that many researchers in rural studies and beyond are simply unimpressed (or just confused) by the relational thinking of such authors as Deleuze, Guattari, Serres or Latour. Many of these researchers remain staunch realists who have little or no patience for the idea that nature might not, in some significant sense, be natural. And, as John Habgood's (2002) book reminds us, ideas of nature still 'perform' in Western societies where their constructedness often goes unnoticed by those deploying them and those feeling their effects. At the same time, even those with a qualified sympathy for post-social approaches to nature - like Castree (2002) and Marsden (2000) are concerned that they risk throwing out the baby with the bathwater in both explanatory and normative terms. They argue that some things 'matter' more than others and resist the incipient 'levelling' effect of some relational worldviews. At the very least, adherence to a 'strategic constructionism' can still yield cognitive and moral gains in this incipient post-constructionist moment in rural studies.

Constructionism, and its naturalist/realist twin, are like 'vampire figures': they are the intellectual undead that still haunt rural researchers' analyses even as other critics try to take them into new ontological and normative waters. This said, we suspect that the pace of academic innovation will soon mean that those remaining constructionist researchers in rural studies fast dwindle in number. The embers of social constructionism are still aglow in rural studies, but for how much longer? One imagines that the term 'social construction' will suffer the same fate as other buzz-terms of the 1990s, like postmodernism. Whatever their intellectual substance, they will decline in popularity because their familiarity ultimately breeds contempt. But this decline may be more apparent than real. Even if 'strong' constructionisms are unlikely to live on, there is, in reality, only a fine-line separating 'weaker' ones from some of the relational approaches the constructionist problematic paved the way for. Symptomatic of this fact, we predict, is that two issues will preoccupy post-constructivist theorists in rural studies just as they have haunted the constructionist research we have reviewed in this chapter. The first is how to identify and distinguish the 'ontological units' that any and all forms of rural analysis need to be able to do in order to make cognitive and normative claims about the world. The second is how to theorize determination: that is, relative balance of cause and effect between these units in any given context. Even if 'construction' will not be the favoured metaphor of a post-constructivist rural studies, it will still be necessary to make justified ontological and moral choices about what exists, what affects what, what should be valued, and on what ground values can be upheld.

\section{ACKNOWLEDGEMENT}

We would like to thank Terry Marsden for constructive comments on an earlier version of this chapter. 


\section{NOTES}

1 In this chapter we choose not to explore the various meanings and referents of the polysemic word 'nature'. This has been done before, most recently by Habgood (2002). Here we use the term nature to signify the nonhuman world, though towards the end of the chapter we discuss the human body also.

2 Labels like these inevitably sloganize rather complex philosophical and normative approaches. In simple terms, actor-network theory challenges the categorical and ontological dualism of society-nature and focuses on the co-constitution of 'social' and 'nature' phenomena. Non-representational theory, associated with Nigel Thrift above all others, emphasizes the lived, practised and contingent nature of all existence.

\section{REFERENCES}

Bartram, R. and Shobrook, S. (2000) 'Endless/end-less natures', Annals of the Association of American Geographers 90 (2): 370-80.

Berger, P. and Luckmann, T. (1967) The Social Construction of Reality. London: Penguin Books.

Brandth, B. (1995) 'Rural masculinities in transition', Journal of Rural Studies 11 (2): 123-33.

Braun, B. (1997) 'Buried epistemologies: the politics of nature in (post)colonial British Columbia', Annals of the Association of American Geographers 87 (1): 3-31.

Braun, B. (2000) 'Producing vertical territory', Ecumene 7 (1): 7-46.

Braun, B. (2002) The Intemperate Rainforest. Minneapolis, MN: Minnesota University Press.

Brechin, G. (1999) Imperial San Francisco. Berkeley, CA: University of California Press.

Bryant, L. (1999) 'The detraditionalisation of occupational identities in farming in South Australia', Sociologia Ruralis 39 (3): 236-61.

Bunce, M. (1994) The Countryside Ideal. London: Routledge. Butler, J. (1993) Bodies that Matter. New York: Routledge.

Castree, N. (2002) 'False antitheses? Marxism, nature and actor-neworks', Antipode 34 (1): 111-46.

Cloke, P. (1997) 'Country backwater to rural village?', Journal of Rural Studies 13 (4): 367-75.

Coulter, J. (2001) 'Ian Hacking on constructionism', Science, Technology and Human Values 26 (1): 82-6.

Cronon, W. (1991) Nature's Metropolis. New York: W.W. Norton.

Demeritt, D. (1998) 'Science, social constructivism and nature', in B. Braun and N. Castree (eds), Remaking Reality. London: Routledge. pp. 173-93.

Demeritt, D. (2001) 'Being constructive about nature', in N. Castree and B. Braun (eds), Social Nature: Theory, Practice and Politics. Oxford: Blackwell. pp. 22-40.

Demeritt, D. (2002) 'What is the social construction of nature?', Progress in Human Geography 2 (3): 255-79.

Eden, S., Tunstall, S. and Tapsell, S. (2000) 'Translating nature', Society and Space 18 (3): 257-72.

Goodman, D. (2001) 'Ontology matters', Sociologia Ruralis 41 (2): 182-200
Goodman, D. and Watts, M. (eds) (1997) Globalizing Food. London: Routledge.

Haan, H. de and Long, N. (eds) (1997) Images and Realities of Rural Life. Assen, Netherlands: Van Gorcum. Habgood, J. (2002) The Concept of Nature. London: Darton, Longman and Todd.

Hacking, I. (1999) The Social Construction of What? Cambridge: Cambridge University Press.

Harvey, D. (1996) Justice, Nature and the Geography of Difference. Oxford: Blackwell.

Henderson, G. (1999) California and the Fiction of Capital. Oxford: Oxford University Press.

Kloppenburg, J. (1986) First the Seed. Cambridge: Cambridge University Press.

Knorr Cetina, K. (2001) 'Postsocial relations', in G. Ritzer and B. Smart (eds), Handbook of Social Theory. London: Sage. pp. 520-37.

Little, J. (1999) 'Otherness, representation and the cultural construction of rurality', Progress in Human Geography 23 (4): 437-42.

Lowe and Ward, N. (1997) 'Field level bureaucrats and the making of new moral discourses in agri-environmental controversies', in D. Goodman and M. Watts (eds), Globalising Food. London: Routledge. pp. 256-72.

Lowe, P., Seymore, S., Ward, N. and Ward, P. (eds) (1997) Moralizing the Environment. London: UCL Press.

Lukacs, G. (1971) History and Class Consciousness. London: New Left Books.

Mann, S. and Dickinson, J. (1978) 'Obstacles to the development of a capitalist agriculture', Journal of Peasant Studies 5 (4): 466-81.

Marsden, T. (2000) 'Food matters and matters of food', Sociologia Ruralis 40 (1): 20-30.

Marsden, T., Murdoch, J., Munton, R., Lowe, P. and Flynn, A. (1993) Constructing the Countryside. Boulder, CO: Westview Press.

Mingay, G. (ed.) (1989) The Rural Idyll. London: Routledge. Murdoch, J. (2003) 'Co-constructing the countryside', in P. Cloke (ed.), Country Visions. Harlow: Pearson. pp. 263-80.

Prudham, S. (2003) 'Taming trees: capital, science and nature in Pacific slope tree improvement', Annals of the Association of American Geographers 93 (3): 636-56.

Rouse, R. (2002) 'Vampires: social constructivism, realism and other philosophical undead', History and Theory 41 (1): 60-78.

Sibley, D. (2003) 'Psychogeographies of rural space and practices of exclusion', in P. Cloke (ed.), Country Visions. Harlow: Pearson. pp. 218-30.

Smith, N. (1984) Uneven Development. Oxford: Oxford University Press.

Thrift, N. (2003) 'Still life in nearly present time: the object of nature', in P. Cloke (ed.), Country Visions. Harlow: Pearson. pp. 308-27.

Vogel, S. (1996) Against Nature. Buffalo: State University of New York Press.

Williams, R. (1973) The Country and the City. Paladin: London. Wylie, J. (2003) 'Landscape, performance and dwelling', in P. Cloke (ed.), Country Visions. Harlow: Pearson. pp. 136-54.

Zimmerer, K. (2000) 'The reworking of conservation geographies', Annals of the Association of American Geographers 90 (2): 356-69. 